Intemational

Jominal of

Jegal Information

\author{
The Official Publication of
}

\title{
The International Association of Law Libraries
}

Printed and Distributed

Compliments of William S. Hein \& Co., Ine. 


\title{
INTERNATIONAL JOURNAL
}

\author{
of \\ LEGAL INFORMATION
}

VOLUME $42 \cdot$ Number $2 \cdot$ SUMMER 2014

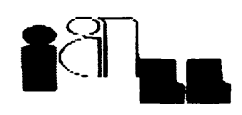

THE OFFICIAL JOURNAL OF THE

INTERNATIONAL ASSOCIATION OF LAW LIBRARIES

http://www.iall.org

Printed and distributed compliments of

William S. Hein \& Co., Inc. 


\begin{abstract}
ADVISORY COMMITTEE ON COMMUNICATIONS
Marci Hoffman (University of California, Berkeley), Chair Mark Engsberg (Emory University), Journal Editor

Mary Rumsey (University of Minnesota), Member at Large Silke Sahl (Columbia University), Member at Large

Aslihan Bulut (Harvard University), Member at Large

Bård Tuseth (University of Oslo), Second Vice President
\end{abstract}

\title{
INTERNATIONAL ASSOCIATION OF LAW LIBRARIES OFFICERS AND DIRECTORS,
} 2013-2016

\author{
Jeroen Vervliet, President \\ Peace Palace Library \\ The Hague, Netherlands \\ Petal Kinder, Immediate Past President \\ High Court of Australia \\ Canberra, ACT, Australia
}

Ruth Bird, First Vice President

Bodleian Law Library

Oxford, England

Bård Tuseth, Second Vice President

University of Oslo

Oslo, Norway

Barbara Garavaglia, Secretary

University of Michigan Law Library

Ann Arbor, Michigan, USA

Xinh Luu, Treasurer

University of Virginia Law Library

Charlottesville, Virginia, USA

Mark D. Engsberg, Ex Officio

Hugh F. MacMillan Law Library

Emory University School of Law Atlanta,

Georgia, USA

Marci Hoffman, Ex Officio

Berkeley Law Library

University of California Berkeley

School of Law

Berkeley, California, USA

Ivo Vogel

Staatsbibliothek zu Berlin

Berlin, Germany
Kristina Alayan

Duke University School of Law

Durham, North Carolina, USA

Daniel Boyer

Nahum Gelber Law Library

McGill University

Montreal, Quebec, Canada

Kurt Carroll

Library of Congress

Washington, DC, USA

Lily Echiverri

University of the Philippines

Espiritu Hall, Diliman

Quezon City, Philippines

David Gee

Institute of Advanced Legal Studies

University of London

United Kingdom

Kerem Kahvecioglu

Istanbul Bilgi University

Istanbul, Turkey 


\section{PURPOSE AND EDITORIAL POLICY}

The International Journal of Legal Information, the official publication of the International Association of Law Libraries, is issued three times a year: Spring, Summer, Winter. It seeks to advance the exchange of legal information throughout the world. Under the direction of its international editorial board and advisors, the $I J L I$ serves the global community of law librarians, legal scholars, and practitioners through the publication of original articles, conference papers, bibliographies, book reviews, documents concerning law and law-related information. The views expressed in such contributions are the responsibility of the individual authors and do not imply the endorsement of the International Association of Law Libraries.

\section{MANUSCRIPT INFORMATION}

Manuscripts and any material intended for inclusion in the $I J L I$ should be addressed to the Editor, Mark Engsberg, who may be reached via email at mark.engsberg@emory.edu. Manuscripts are to be submitted in MS Word or WordPerfect as an attachment.

Single copy requests and current claims, should be sent to: Mark Engsberg, IJLI Editor

Emory Law Library, 1301 Clifton Road

Atlanta, GA, 30322, USA

Tel.:(404)727-6983; Fax:(404)727-2202

mark.engsberg@emory.edu

All bibliographies should contain complete bibliographic information and follow The Chicago Manual of Style, 16th ed. (Chicago, 2003).

Book reviews and books for view should be sent directly to:

$$
\begin{gathered}
\text { Thomas W. Mills, Book Review Editor } \\
\text { Cornell University Law Library } \\
\text { 340B Myron Taylor Hall } \\
\text { Ithaca, NY 14853-4901, USA } \\
\text { Twm26@cornell.edu }
\end{gathered}
$$

\section{MEMBERSHIP AND SUBSCRIPTION INFORMATION}

Current information about the $I A L L$, its members and activities can be found at http://www.iall.org.

$I A L L$ membership includes subscription to the IJLI. Checks should be made out to the International Association of Law Libraries and sent to the Association's P.O. Box at the address above.

Individual: Student membership - US\$20; Personal membership - US\$95 (North America, the EU, EEA, Australia and New Zealand; US\$60 All other countries), Institutional membership US\$130.

Back issues of the $I J L I$ are available in hardcopy and in microfiche. Please contact William S. Hein and Co., Inc., 1285 Main Street, Buffalo, N.Y., 14209-1987, USA, Tel.: (800)828-7571 or (716)882-2600; Fax: (716)883-8100; email: wsheinco@class.org.

Copyright by the International Association of Law Libraries.

Library of Congress Card No. 82-643460; ISSN 0731-1265. Printed in the United States. 


\section{CONTENTS}

EDITORIAL COMMENT

Mark D. Engsberg vii

ARTICLES

Citing Sources or Mitigating Plagiarism: Teaching Law Students the Proper Use of Authority

Attribution in the Digital Age

DeCarlous Y. Spearman 177

The International Information Consultant: A Primer on Avoiding Potholes, Perils, and Pitfalls

Catherine Lemmer 220

International Trade Law and Information Policy:

A Recent History

Genevieve Tung 241

Three Faces of Information Literacy in Legal Studies:

Research Instruction and Law Student Information Literacy

Standards in the American Common Law, British Common

Law, and Turkish Civilian Legal Traditions

Dennis Kim-Prieto and Mustafa Kerem Kahvecioğlu 293

140 Characters of Less: An Experiment in Legal

Research

Patrick M. Ellis 303

Research Guide to European Data Protection Law

Steven S. McCarty-Snead and Anne Titus Hilby 348

BOOK REVIEWS

Little Angels: An International Legal Perspective on

Child Discrimination

Mary Beth Chappell Lyles 418

Defamation Law and Social Attitudes: Ordinary

Unreasonable People

Michael C. Duff 420

Legislating for Equality: A Multinational Collection

of Non-discrimination Norms, Vol. 1: Europe

Mary Rumsey 424

Law as Engineering: Thinking About What Lawyers Do

Nina Scholtz 426

INTERNATIONAL CALENDAR

Aslihan Bulut 428 